\title{
EVALUATION OF BEE DIVERSITY WITHIN DIFFERENT SWEET CHERRY ORCHARDS IN THE SULTANDAĞI RESERVOIR (TURKEY)
}

\author{
Yasemin Güler ${ }^{1 *}$ \\ Fatih Dikmen ${ }^{2}$ \\ Ayșe Özdem ${ }^{1}$

\begin{abstract}
1Plant Protection Central Research Institute, Department of Agricultural Fauna and Microflora, FSM Bulvari No:66 Yenimahalle, 06172 Ankara, Turkey

IIstanbul University, Faculty of Science, Department of Biology, Beyazit, 34452 Fatih/lstanbul, Turkey
\end{abstract} \\ *corresponding author: yaseminguler@gmail.com \\ Received 13 June 2014; accepted 8 July 2015
}

\begin{abstract}
Many varieties of sweet cherry are self-incompatible. Therefore, sweet cherry orchards require a huge population of pollinator bees to carry out an adequate amount of pollen transfer between the different varieties. Our study was conducted to evaluate the differences in the richness and diversity of these pollinators within very closely located sweet cherry orchards, and to understand the underlying effects causing these differences. The study was conducted in the Sultandağı Reservoir (Turkey) which covers the towns of Sultandağı (Afyonkarahisar) and Akșehir (Konya). In order to avoid a sampling bias, Malaise traps were used to collect bee samples. Sampling collections were repeated for three years; from 2007 to 2009, between April and May. The traps were set in the bud-swell period and lifted in the green-fruit period. Climatic data were taken from meteorology stations near the orchards. Vegetation in the surrounding areas was also inspected. The composition of pollinator bee species was determined and compared between orchards. In total, 83 bee species and 38 plant species were recorded. It was found that Halictidae is the most abundant and richest group among the pollinator bees. The effects of the quantity of the Malaise traps on bee sampling success were also tested. It was found that one trap per 325 trees is enough for an adequate sampling. Apart from the annual fluctuations of bee richness in the orchards, general differences in the bee diversity among orchards might be affected by the surrounding vegetation and especially from different agricultural practices such as tilling the ground.
\end{abstract}

Keywords: Apoidea, bee diversity, Malaise trap, sweet cherry, tillage, weed control.

\section{INTRODUCTION}

Sweet cherry [Prunus avium (L.) Moench] requires pollinators to facilitate the cross-pollination because a lot of varieties are self-incompatible (Bosch and Kemp, 1999; Delaplane and Mayer, 2000). The honeybee is frequently used for the pollen transfer from the polliniser variety to the target variety, to set fruit in marketable quantities (Delaplane and Mayer, 2000). In sweet cherry's blooming time, in a temperate climate (including the orchards located on lowland of Turkey), the pollination activities of the honeybee can be limited because of rainy weather conditions and lower tempera- tures (Roversi and Ughini, 1996; Huang, 2003). However, in such regions some native bee species can continue their pollination activities under these conditions (Vicens and Bosch, 2000; Güler and Dikmen, 2013). Therefore, conservation of native bee pollinators in the vicinity of cherry orchards helps assure continuing pollination. However, pollination service is also under threat as a result of intensification of farming practices. It is known that many pollinator bees have declined dramatically in recent decades in continental Europe and in North America (Goulson, 2003). Özbek and Zanden (1996) reported that pollinator bee populations have been declining in Turkey because of habitat destruction 
and overuse of pesticides. The data to quantitatively prove these stated declines in Turkey is not yet available. The research studies which would be needed to provide the required data would have to include long-term monitoring programs and unbiased sampling methods that assess the effects of different agricultural practices on pollinator bees. Besides the colored pan traps, the Malaise trap is one of the best unbiased sampling methods. The Malaise trap is frequently preferred for taxonomic studies, field surveys, and ecological studies that are concerned with species diversity, dominance, and abundance in ecosystems (Steffan-Dewenter and Leschke, 2003; Oertli et al., 2005; Rossi et al., 2006; Irvine and Woods, 2007). The Malaise trap is also suggested for capturing flying insects such as the Hymenopteran groups (Fraser et al., 2008).

The Sultandağı reservoir is located between Akșehir Lake and Sultandağı Mountain. A huge part of the agricultural area in the reservoir is composed of irrigated farmlands, including cherry, apple, and especially sweet cherry orchards. Almost all of the sweet cherries grown in this reservoir are exported. Most of the orchard owners are conscious growers and have adopted integrated pest and crop management programmes (IPCM). For this reason, their agricultural practises bear a strong resemblance to each other. Only some minor differences can be observed in the irrigation systems and weed control methods they use. Although 168 bee species were recorded as flower-visitors of temperate fruit trees in Turkey (Özbek, 2008; Güler and Dikmen, 2013), this species richness and the abundance of pollinator bee communities in the orchards have never been compared. Nor have the effects of the agricultural practices on the diversities of the pollinator bee communities ever been evaluated in Turkey. For these reasons our study, mainly focused on comparing the diversity of the pollinator bee fauna where there were closely located sweet

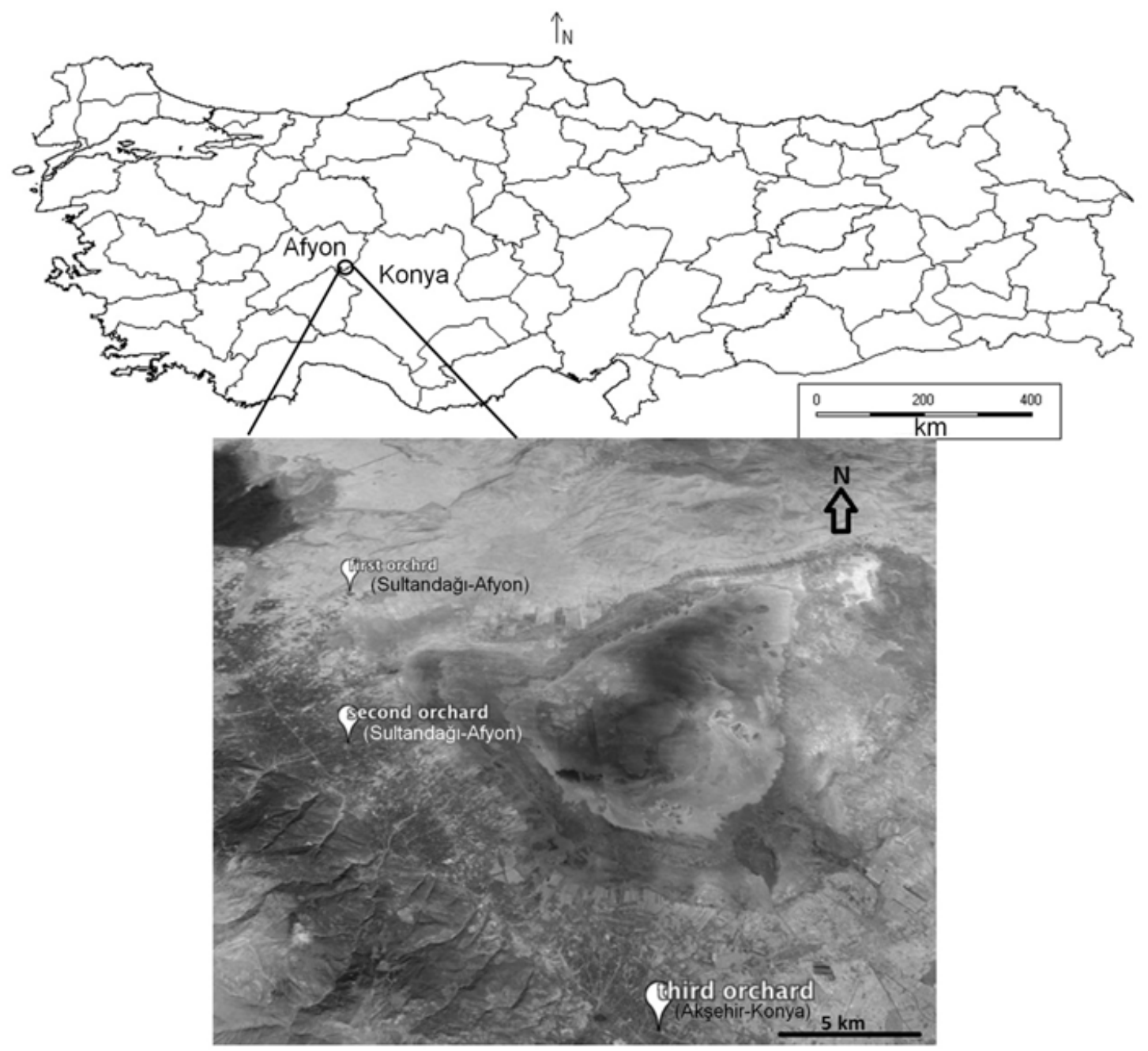

Fig. 1. Brief description of the study area: map of Turkey displaying the province borders and cross-section of the Sultandağı Reservoir. 
cherry orchards, in the Sultandağı Reservoir. Our study dealt with sweet cherry orchards which have different types of weed control and irrigation systems in the Sultandağı Reservoir. In addition, the plant composition of the orchards in the blooming period was inspected to see whether the different pollen sources had any effects on the abundance of the pollinator bees. The effects of the quantity of the Malaise traps on the bee sampling success were also tested to see if these traps are suitable for such monitoring studies on pollinator bees.

\section{MATERIAL AND METHODS}

\section{The study area}

The field survey was conducted in the three sweet cherry orchards in the towns of Sultandağ (the first orchard $38^{\circ} 35^{\prime} 03.69^{\prime \prime} \mathrm{N}, 31^{\circ} 16^{\prime} 46.70^{\prime \prime} \mathrm{E}$ and the second orchard 38 $29^{\prime} 54.57^{\prime \prime} \mathrm{N}, 31^{\circ} 17^{\prime} 14.04^{\prime \prime} \mathrm{E}$ ) and Akssehir (the third orchard $38^{\circ} 23^{\prime} 22.44^{\prime \prime} \mathrm{N}$, $\left.31^{\circ} 23^{\prime} 31.49 " \mathrm{E}\right)$, located in the southwest of Turkey (Fig. 1). Sampling locations were at least $14-17 \mathrm{~km}$ away from each other. The altitudes of the orchards were nearly similar $(967,982$, and $1007 \mathrm{~m}$, respectively). There were 1675 trees in three orchards, including the 0900 Ziraat (1255 trees), Bing, Gilli, and Stella (420) cultivars. The latter three cultivars were the polliniser varieties and their proportion against the 0900 Ziraat cultivar was $1 / 4$.

An Integrated Pest Management Program (IPM) has been put to use in all of the orchards. While the weeds in the first orchard were periodically mowed, the ground in the third orchard was tilled. There were no serious changes done to the ground under the cherry trees in the second orchard. A drip irrigation system was used in the first and third orchard, while a flood irrigation system was used in the second orchard. Such properties of the orchards are summarised in Table 1.

Bee samples were collected by Malaise traps and prepared for the collection. Daily climatic data such as temperature, relative humidity, and rain frequency, were obtained from meteorology stations (iMETOS pro 300) established in Sultandağı and Akșehir,

and data were summarised in Tables 2-3. A map of Turkey displaying the province borders was obtained via DIVA-GIS (Hijmans et al., 2005). A cross-section of the Sultandağı Reservoir and the schematic views of the orchards were gathered from Google Earth v7.1.2.2041. The borders, scale, and North mark (N) were labeled on the figures via Paint.NET ${ }^{\circ}$ v3.5.10.

\section{Setting up Malaise Traps}

For a better sampling procedure a test study was carried out in 2007. At this time, the effects of the quantity of the Malaise traps on the bee sampling success was evaluated. Only the first orchard, which contains 1000 trees (5.5 hectare area), was used in this test study. Ten traps (one trap per 100 trees) were used (Fig. 2b). After the test study, one trap per 325 trees (ca 1.9 hectare area), which was the minimum number of trees in the orchards, was decided for use in the study in 2008 and 2009. This meant the first orchard contained three traps and the latter two orchards contained one trap each (Fig. 2c-e). The bee samples collected by these five traps were evaluated to compare the faunal compositions of the orchards.

The Malaise trap model used in the study was Townes style (Townes, 1972) (Fig. 2a). The traps were placed at the centre of each orchard so as not to be affected from the surrounding vegetation outside of the orchards. The traps were set in the bud-swell period and lifted in the green-fruit period. Malaise traps were controlled daily in the blooming period and every fortnight in the bud-swell period and the green fruit-period.

\section{Identification of Plant Samples}

To explore the plant composition of the orchards and the surrounding area, plant specimens were collected, pressed and transferred to the herbarium. The plant specimens were identified by Dr. Mutlu and Ms. Güzel (M.Sc.). All of the collected specimens were deposited in the Plant Protection Museum of the Plant Protection Central Research Institute, Ankara (Turkey).

Table 1.

Different features of the orchards

\begin{tabular}{cccc}
\hline & $\mathbf{1}^{\text {st }}$ orchard & $2^{\text {nd }}$ orchard & $3^{\text {rd }}$ orchard \\
\hline Location & Sultandağı & Sultandağı & Akșehir \\
\hline Number of trees & 1000 & 325 & 350 \\
\hline Disturbances to the ground & Periodic mowing & No & Tillage \\
\hline Irrigation system & Drip & Flood & Drip \\
\hline
\end{tabular}



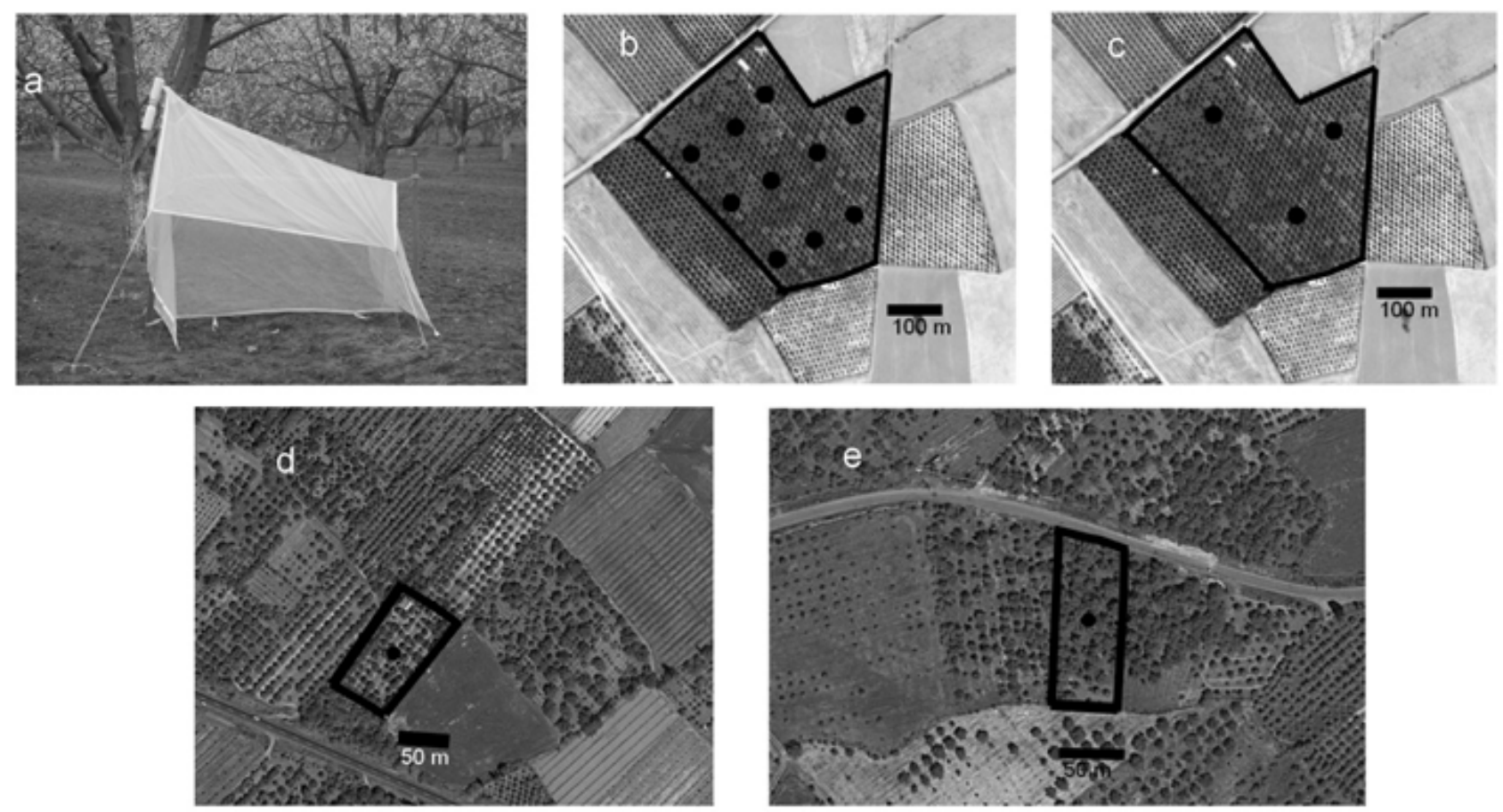

Fig. 2. Description of the study area; a: Malaise traps used in the orchards, b-e schematic maps of the orchards displaying the amount and locations of the traps - seen as black circles, b: first orchard (ten traps) c: first orchard (three traps), d: second orchard (one trap), e: third orchard (one trap).

\section{Identification of Bee Pollinators}

Species identification was based on Ebmer (1969), Pesenko (1978, 1984, 1985, 1986), Pesenko et al. (2000), and Amiet et al. (2001) for Halictidae; Scheuchl (2000) and Terzo et al. (2007) for Anthophoridae; Osychnyuk et al. (1978), Banaszak and Romasenko (1998), Michener (2000), Amiet et al. (2004), and Scheuchl (2006) for Megachilidae. These specimens were additionally compared with the bee collections of the Natural History Museum of Vienna, Austria (NHMW), Oberösterreichisches Landesmuseum- Biologiezentrum of Linz, Austria (OLML), Zoologische Staatssammlung, Munich, Germany (ZSM), and the Polish Institute of Zoology (ZIN). Determinations of Andrena spp. (Hym.: Andrenidae) were carried out by Dr. Tomozei. Identifications of the Eucerini tribe (Hym.: Anthophoridae/Apidae) were carried out by Mr. Risch. The honeybee, Apis mellifera L. was not included in the study.

\section{Statistica analysis}

The abundance $(\mathrm{N})$ and the richness $(\mathrm{S})$ of the bee populations were estimated from the dataset of field studies conducted in 2007 - 2009. However, the bee diversities of the orchards were estimated from the dataset of the field studies conducted in 2008-2009. Species diversity was calculated using the Shannon-Wiener diversity index $\left(\mathrm{H}^{\prime}\right)\left(\mathrm{H}^{\prime}=-\Sigma\right.$ pi In pi; where pi is the proportion of individuals of the $i^{\text {th }}$ species found in the habitat). Shannon Hmax (maximum possible diversity) score is the logarithmic expression of the species richness [Hmax $=\ln (\mathrm{S})$ ] and was used in the study to compare the orchards. Shannon J' is the evenness index score. When abundances are equal or close to each other this score is higher (maximum score is 1). So the low values are related with the dominancy and unequal abundances (rare species). All the calculations were made using BioDiversity Professional statistics analysis software (McAleece et al., 1997).

\section{RESULTS}

\section{Effect of the quantity of Malaise traps on the sampling success}

As a result of the test study in 2007, a total of 1680 bee specimens were collected by 10 traps located in the first orchard (Appendix 1). When the number of the traps decreased (from ten to three) in the following years, the number of collected specimens also decreased (445 specimens in 2008, 665 specimens in 2009) (Appendix 1). The species richness between the years was also different. Seventy species were collected from the first orchard 
in 2007, 33 species in 2008, and 39 species in 2009 (Appendix 1). Whereas 26 species collected in 2007 were not recorded in the consecutive years, 21 species including the most frequently encountered ones, were found every year in the first orchard.

\section{Characterisation of the bee fauna and orchard vegetation}

At the end of the three-year study, a total of 3156 bee individuals were recorded from the three orchards. Identification was made of 83 bee species from 12 genera. Only Sphecodes albilabris (Fabricius) was excluded from the analyses since it is cleptoparasite. All species and their abundances were listed in Appendix 1. According to this, 70 pollinator bee species were recorded at 2007, and 62 species were recorded from the consecutive years. Halictidae was the richest (64 spp.) and most abundant ( $\mathrm{N}: 2156)$ bee family (Fig. 3, 4). The number of identified species in other families were similar (Apidae: 9 spp; Andrenidae: 5 spp; Megachilidae: 5 spp.). The second most abundant bee family was Andrenidae (N: 525), followed by Apidae (N: 331) and Megachilidae ( $\mathrm{N}: 145)$. The most abundant and diverse genus was Evylaeus Robertson with representatives of 33 species. The most abundant species was Evylaeus marginatus (Brulle) (N: 370$)$, followed by $E$. malachurus (Kirby) ( $N$ : 346) and $E$. linearis (Schenck) (N: 313).

Cubitalia parvicornis (Mocsáry), Evylaeus linearis, and $E$. morio (Fabricius) were found in each orchard, every year. Andrena dorsata (Kirby), A. flavipes Panzer, A. thoracica (Fabricius), E. malachurus,
E. marginatus, and Osmia caerulescens (L.) were found in the first and second orchard every year. E. brevicornis (Schenck), E. calceatus (Scopoli), E. trichopygus (Blüthgen), and O. melanura Morawitz were only found in the second orchard.

As a result of the identifications of the plant specimens, 38 species were determined from the study area (Appendix 2). It was found that Brassicaceae (8 species) and Asteraceae (5 species) were the most frequently encountered families with the highest number of species in the orchards. The first and second orchards had a total number of 26 and 25 plant species, consecutively. The third orchard was very poor and only had 5 plant species which were mainly out of the range of the pollinator bees' interest.

\section{Comparison between orchards}

After the test study in 2007, all orchards were monitored with a total of 5 traps (Fig. 2c-e). The pollinator bee abundance data belonging to 2008 and 2009 were evaluated separately at first, and then combined (Tab. 4) for overall scores. In every case, the $\mathrm{S}, \mathrm{N}, \mathrm{H}^{\prime}$, and Hmax scores were lowest in the third orchard (except $\mathrm{H}^{\prime}$ in 2008) but the J' scores of this orchard were higher than the others or nearly equal. In 2008, the $\mathrm{S}, \mathrm{N}, \mathrm{H}^{\prime}$, and Hmax scores of the first orchard were higher, but lower (except for $\mathrm{N}$ ) in 2009. All total, the second orchard had the highest diversity index scores and seemed to be the most diverse and most equally abundant one (Tab. 4).

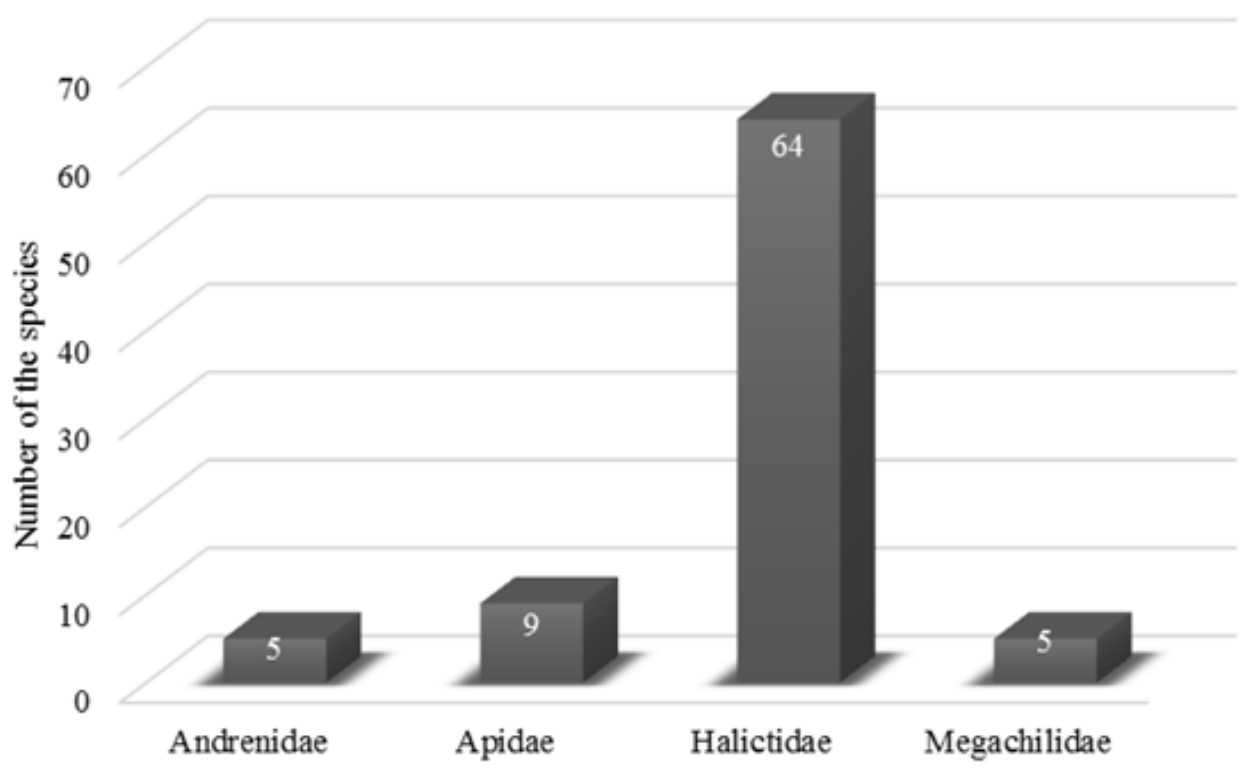

Fig. 3. The total number of bee species collected from the sweet cherry orchards during the three years. 


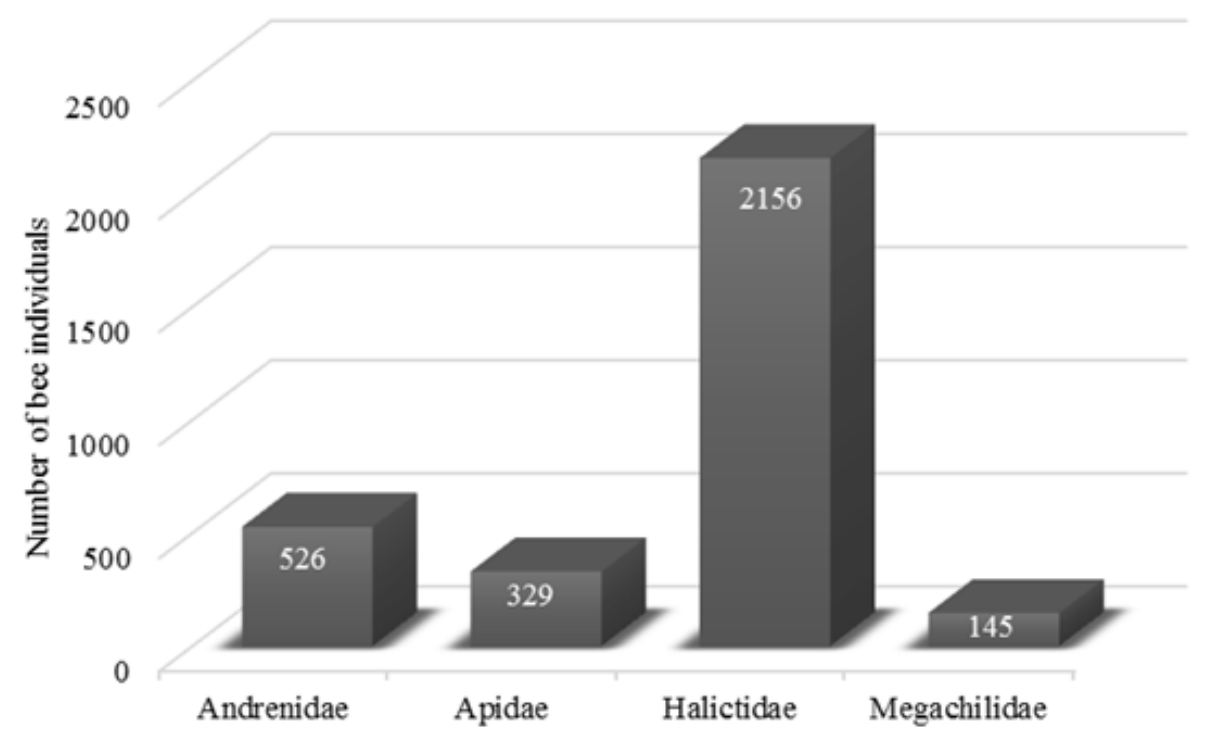

Fig. 4. The total number of bee individuals collected from the sweet cherry orchards during the three years.

\section{DISCUSSION}

Effect of the Malaise trap on the sampling success Güler (2011) and Güler et al. (2011) used the sweep-net and aspirator to collect bee specimens. They reported a total of 130 pollinator bee species from the Afyonkarahisar province. In our study, we used only the Malaise traps, and 83 bee species were recorded just from the sweet cherry orchards of the Sultandağı Reservoir. When compared with the classical methods, this data suggests that the sampling success of the Malaise traps were also quite satisfactory. Besides, sweeping would not be an appropriate method for sampling bee specimens in the orchards because the trees were 3 - 5 meters high or higher. Malaise traps work well under sunny weather conditions since they have a mechanism which tends to capture fast flying insects. Due to this fact we can expect to collect more specimens in the orchards where the mean temperature is relatively higher. For Sultandağı, the mean temperature of the whole study period was nearly $14^{\circ} \mathrm{C}$ in $2007,12.7^{\circ} \mathrm{C}$ in 2008 , and $11.3^{\circ} \mathrm{C}$ in 2009 . According to Appendix 1, the species richness and abundance of the bee specimens were also much higher in 2007. However, this could be due to the higher trap proportion in 2007 (10 traps were used). When the trap proportion was decreased ( 3 traps all total) in the ensuing years, the collected bee individuals decreased in the first orchard (Appendix 1). If we compare the data of 2008 and 2009, we can see that there are minor differences between the species richness and bee abundances of the first orchard. So we may conclude that the sharp decrease between the data of 2007 and 2008 could be due to the trap proportion, and the minor differences between 2008 and 2009 could be due to the weather conditions (Tab. 2). Nevertheless, if we look closer at the species list on Appendix 1, we may see that the core pollinator groups (more abundant species that will potentially have more of a chance to pollinate) were sampled in all the years. So we may conclude that: a) Malaise traps can be used for obtaining samples of the pollinator bee groups, especially in monitoring studies in such orchards, b) one trap per 325 trees (one trap per 1.9 hectare area) is enough for an adequate sampling, c) for more accurate sampling, one trap per 200 - 300 trees (1 - 1.5 hectare area) might be better.

\section{Bee fauna and their interaction with their floral resources}

Our general result concerning the pollinator bee diversity of the sweet cherry orchards was congruent with previous studies, such as Al-Ghzawi et al. (2006) and Özbek (2008). Tuell et al. (2009) stated that members of the subfamily Halictinae and members of the genus Andrena were the most encountered bees species captured in the high-bush blueberry agro-ecosystems. Lasioglossum marginatum Brulle (also referred to as Evylaeus marginatus; which is also the version we used in our study) were found as the most abundant bee species in the olive groves of Greece (Tscheulin et al., 2011). All these studies also suggested that the Halictidae species were the most abundant and 
Table 2.

Summary of the weather conditions in Sultandağı

\begin{tabular}{|c|c|c|c|c|c|c|c|c|c|}
\hline & \multicolumn{3}{|c|}{ The bud-swell period } & \multicolumn{3}{|c|}{ The full-blooming period } & \multicolumn{3}{|c|}{ The green-fruit period } \\
\hline & 2007 & 2008 & 2009 & 2007 & 2008 & 2009 & 2007 & 2008 & 2009 \\
\hline Date & $\begin{array}{c}16-25 \\
\text { April }\end{array}$ & $\begin{array}{c}10-14 \\
\text { April }\end{array}$ & $\begin{array}{l}8-19 \\
\text { April }\end{array}$ & $\begin{array}{l}26 \text { April } \\
\text { - } 3 \text { May }\end{array}$ & $\begin{array}{c}15-22 \\
\text { April }\end{array}$ & $\begin{array}{c}20-30 \\
\text { April }\end{array}$ & $\begin{array}{l}\text { 4- } 24 \\
\text { May }\end{array}$ & $\begin{array}{l}23 \text { April } \\
-15 \text { May }\end{array}$ & $\begin{array}{l}1-20 \\
\text { May }\end{array}$ \\
\hline $\begin{array}{c}\text { The mean } \\
\text { temperature } \\
\left({ }^{\circ} \mathrm{C}\right)\end{array}$ & 7.9 & 15.3 & 8.9 & 12.2 & 14.8 & 9.8 & 17.7 & 11.3 & 13.4 \\
\hline Below $12^{\circ} \mathrm{C}$ & 9 days & 1 day & 11days & 2 days & 3 days & 8 days & - & 14 days & 10 days \\
\hline Rainfall & 1 day & - & 3 days & 6 days & 1 day & 3 days & 2 days & 4 days & 5 days \\
\hline $\begin{array}{l}\text { The mean } \\
\text { rainfall }(\mathrm{mm})\end{array}$ & 2.8 & - & 1.8 & 39.48 & 0.2 & 0.95 & 0.4 & 3 & 5.4 \\
\hline
\end{tabular}

Table 3.

Summary of the weather conditions in Akșehir

\begin{tabular}{ccccccc} 
& \multicolumn{2}{c}{$\begin{array}{c}\text { The bud-swell } \\
\text { period }\end{array}$} & $\begin{array}{c}\text { The full-blooming } \\
\text { period }\end{array}$ & \multicolumn{2}{c}{$\begin{array}{c}\text { the green-fruit } \\
\text { period }\end{array}$} \\
\cline { 2 - 7 } & 2008 & 2009 & 2008 & 2009 & 2008 & 2009 \\
\hline Date & $\begin{array}{c}10-14 \\
\text { April }\end{array}$ & $\begin{array}{c}8-19 \\
\text { April }\end{array}$ & $\begin{array}{c}15-22 \\
\text { April }\end{array}$ & $\begin{array}{c}20-30 \\
\text { April }\end{array}$ & $\begin{array}{c}23 \text { April }- \\
15 \text { May }\end{array}$ & $\begin{array}{c}1-20 \\
\text { May }\end{array}$ \\
\hline $\begin{array}{c}\text { The mean temperature } \\
\left({ }^{\circ} \mathrm{C}\right)\end{array}$ & 16.7 & 9.6 & 16.0 & 10.3 & 11.3 & 13.9 \\
\hline Below $12^{\circ} \mathrm{C}$ & 1 day & 10 days & 3 days & 7 days & 13 days & 10 days \\
\hline Rainfall & - & 3 days & - & 5 days & - & 9 days \\
\hline The mean rainfall $(\mathbf{m m})$ & - & 4.3 & - & 2.04 & - & 7.9 \\
\hline
\end{tabular}

Table 4.

Annual changes in the species richness and diversity of pollinator bees, in the three sweet cherry orchards

\begin{tabular}{|c|c|c|c|c|c|c|c|c|c|}
\hline & \multicolumn{3}{|c|}{$\begin{array}{c}1^{\text {st }} \text { orchard } \\
\text { (three traps) }\end{array}$} & \multicolumn{3}{|c|}{$\begin{array}{l}2^{\text {nd }} \text { orchard } \\
\text { (one trap) }\end{array}$} & \multicolumn{3}{|c|}{$\begin{array}{l}3^{\text {rd }} \text { orchard } \\
\text { (one trap) }\end{array}$} \\
\hline & 2008 & 2009 & $\begin{array}{c}2008+ \\
2009\end{array}$ & 2008 & 2009 & $\begin{array}{c}2008+ \\
2009\end{array}$ & 2008 & 2009 & $\begin{array}{c}2008+ \\
2009\end{array}$ \\
\hline Number of species (S) & 33 & 39 & 51 & 16 & 43 & 46 & 12 & 15 & 21 \\
\hline $\begin{array}{l}\text { Number of individuals } \\
\text { (N) }\end{array}$ & 445 & 665 & 1110 & 80 & 221 & 301 & 29 & 36 & 65 \\
\hline $\begin{array}{c}\text { Shannon H'(diversity } \\
\text { index score) }\end{array}$ & 1.09 & 1.14 & 1.23 & 0.92 & 1.44 & 1.42 & 0.98 & 1.03 & 1.19 \\
\hline $\begin{array}{c}\text { Shannon Hmax (richness } \\
\text { index score) }\end{array}$ & 1.52 & 1.60 & 1.71 & 1.20 & 1.63 & 1.66 & 1.08 & 1.18 & 1.32 \\
\hline $\begin{array}{c}\text { Shannon J'(evenness } \\
\text { index score) }\end{array}$ & 0.66 & 0.72 & 0.72 & 0.77 & 0.88 & 0.85 & 0.91 & 0.88 & 0.90 \\
\hline
\end{tabular}

richest bee groups found in the orchards. Besides the fact that the Halictidae species being the most abundant found in our study, Evylaeus marginatus, $E$. malachurus, and $E$. linearis were also recorded as the most frequently encountered species in the Mediterranean Region of Turkey (Dikmen, 2012). Dikmen (2012) also reported that Evylaeus species of the Mediterranean region of Turkey are mostly captured on the Asteraceae species, such as Crepis spp., Centaurea spp., and Echinops spp. The recorded plants (Appendix 2) of the orchards were also mainly from Asteraceae and this situation might also have positive effects on the abundance of these species. According to Pesenko et al. (2000), these species are widely distributed in the steppe habitat of southern Europe and southern Asia. These species 
are also a primitive eusocial species (Pesenko et al., 2000) which means that they have the capability to reach high population levels in suitable habitats. For example, E. marginatus forms the largest colonies among all of the halictids (Pesenko et al., 2000). Our study area could be such a suitable environment favoring the high abundances of these species.

Another most frequently encountered species was Andrena flavipes. This species has a solitary, bivoltine, and polylectic lifestyle. It is a common species in which the spring generation emerges in early spring (Tadauchi and Matsumura, 2007). Maybe because of its phenology, the populations of these species were high at the time our study was conducted. Güler and Sorkun (2010) analysed the pollen loads carried by $A$. flavipes specimens captured from the same area. According to their study, the dominant pollen loads belonged to the members of Brassicaceae, and the sweet cherry pollens were also preferred afterwards.

One of the main outputs of the study was the records about the Osmia species. Members of this genus are used as an alternative to honeybee pollinators in fruit gardens (Bosch et al., 2000; Vicens and Bosch, 2000; Huang, 2003). Therefore, it was important in our study to find members of this genus and explore their species richness in the sweet cherry orchards. Although four species were found (Appendix 1), the abundance of these species was fairly low in the orchards. There were two particular species, 0 . bicornis (L.) and 0 . caerulescens, which were found to be potentially useful. Güler and Dikmen (2013) reported that both species were active in the sweet cherry blooming period, and 0 . bicornis could even maintain its activities in air temperatures below $12^{\circ} \mathrm{C}$. Therefore, rearing these species using artificial nests may increase their population size. So far, only one study related that the artificial nesting of these species had been carried out in Turkey (Güler, 2012). However, the results of this study have not come into practice yet.

\section{Comparison between orchards}

Since the annual fluctuations of the weather conditions were very similar (as expected) to each other between Sultandağı and Akșehir (Tab. 2 and 3), it was concluded that the vegetation of the orchards and the differences in agricultural practices may have some influence on the abundance and richness of the pollinator bee species. The vegetation cover of the orchards could be an important factor on bee diversity. Holzschuh et al. (2007) reported that the diversity of flowering plants have positive effects on bee diversity. The weeds under trees serve as an alternative food source for early flying bees before the cherry flowers are in full bloom. Likewise, Bosch et al. (2000) observed that Osmia lignaria Say populations survived by feeding on Taraxacum sp. when there were no flowers on the cherry trees, before the blooming period. The majority of the pollinator bees captured in this study made their nests in the ground or they used the natural substrates on the ground for a nest. Due to this fact, any disturbances to the ground might seriously affect their populations. To evaluate this assumption, bee diversity data of 2008 and 2009 of all the orchards were inspected, and the effects of different agricultural practices such as tilling, mowing, and flood irrigation were examined. According to Table 4, the third orchard was found to have the poorest diversity scores. Since the third orchard's irrigation system (Tab. 1) was safe (drip), tilling the ground might be the main factor for the low diversity scores in this orchard. Tilling the ground not only removes the weeds (so called vegetation under trees) but also may destroy the alternative pollen diet and nests of the ground nesting bees. Sharley et al. (2008) found that ant (Formicidae: Hymenoptera) populations in a vineyard were affected by tillage. Maybe because of these factors the abundance of the bees in the third orchard was low. On the other hand, according to Appendix 2, the vegetation cover of the orchards under cherry trees was also poor in the third orchard. This could be another factor negatively affecting the pollinator bee abundance. The other two orchards had more rich vegetation and their species richness of the pollinator bees was also higher. Mowing could be safer than tilling because it does not damage the soil or the nests. Steffan-Dewenter and Leschchke (2003) also stated that mowing has insignificant effects on insect communities of orchard meadows. The diversity scores of the first orchard also support this assumption (Tab. 1 and 4). Maybe because there was no disturbance to the ground in the second orchard, the Shannon diversity scores were higher, than for the other orchards. In addition, according to the data of second orchard, we may make infer that flood irrigation had no effect on the ground nesting pollinator bee population.

\section{CONCLUSION}

Turkey has very rich pollinator bee diversity like other insects and plant species, due to its biogeographic position. However, most of the farmers in Turkey are not sufficiently aware of the importance 
of these other pollinator bee groups. Therefore, the bee fauna in the orchards should be revealed and the alternative pollinator bee species should be determined for efficient agricultural practices. We aim to help fill these gaps in this area with this study and the former studies (Güler et al., 2011; Güler, 2012; Güler and Dikmen, 2013). Developing an alternative pollinator strategy which takes into consideration the farming system, landscape, and regional context, would be possible with the help of these kinds of data.

\section{ACKNOWLEDGMENTS}

The authors wish to thank Dr. Tomozei (Museum of Natural Sciences "Ion Borcea" Bacău, Romania) for determining the Andrena spp. (Andrenidae), Dr. Risch (Leverkusen, Germany) for determining the Eucerini (Anthophoridae) tribe, Dr. Mutlu (Inönü University, Malatya, Turkey), and Ms. Güzel (M.Sc) (Plant Protection Central Research Institute, Ankara, Turkey) for the diagnosis of herbarium materials in the manuscript. Yasemin Güler received support from the TÜBITAK 2219- International Post-Doctoral Research Fellowship Programme for her visit to ZSM and OLML. Fatih Dikmen also received support from the SYNTHESYS Project http://www. synthesys.info/ which is financed by the European Community Research Infrastructure Action under the FP6 "Structuring the European Research Area" programme for his visit to NHMW and ZIN.

The research was financially supported by the General Directorate of Agricultural Research, Ministry of Agriculture and Rural Affairs.

\section{REFERENCES}

Al-Ghzawi A., Zaitoun S., Mazary S., Schindler M., Wittmann D. (2006) Diversity of bees (Hymenoptera, Apiformes) in extensive orchards in the highlands of Jordan. Arxius de Miscellània Zoològica 4: 42-48.

Amiet F., Herrmann M., Müller A., Neumeyer R. (2001) Fauna Helvetica: Apidae 3. Halictus, Lasioglossum. Centre Suisse de Cartographie de la Faune (CSCF)/Schweizerische Entomologische Gesellschaft (SEG). Neuchatel. 208 pp.

Amiet F., Herrmann M., Müller A., Neumeyer R. (2004) Fauna Helvetica 9, Apidae 4 (Anthidium, Chelostoma, Coelioxys, Dioxys, Heriades, Lithurgus, Megachile, Osmia, Stelis). Centre Suisse de Cartographie de la Faune (CSCF)/
Schweizerische Entomologische Gesellschaft (SEG). Neuchatel. 273 pp.

Banaszak J., Romasenko L. (1998) Megachilid bees of Europe. Pedagogical University of Bydgoszcz. Bydgoszcz, Poland. 239 pp.

Bosch J., Kemp W. P. (1999) Exceptional cherry production in an orchard pollinated with blue orchard bees. Bee World 80(4): 163-173.

Bosch J., Kemp W. P., Peterson S. S. (2000) Management of Osmia lignaria (Hymenoptera: Megachilidae) populations for almond pollination: methods to advance bee emergence. Environmental Entomology 25(5): 874-883.

Delaplane K. S., Mayer D. F (2000) Crop pollination by bees. CABI Publishing Cambridge. M.A., USA. 352 pp.

Dikmen F. (2012) Akdeniz Bölgesi Halictidae (Apiformes: Apoidea: Hymenoptera) familyası üzerinde sistematik çalıșmalar. Hacettepe Üniversitesi Fen Bilimleri Enstitüsü. 2012-D-6085 nolu Doktora tezi. 22.06.2012. 343 pp.

Ebmer A. W. (1 969) Die bienen des genus Halictus Latr. s. I. im grossraum von Linz (Hymenoptera, Apidae): systematik, biogeographie, ökologie und biologie mit berücksichtigung aller bisher aus Mitteleuropa bekannten Arten, teil I. Naturkundlichen Station der Stadt Linz 15: 133-183..

Fraser S. E. M., Dytman C., Mayhew P. J. (2008) The effectiveness and optimal use of malaise trap for monitoring parasitoid wasps. Insect Conservation and Diversity $1: 22-31$

Goulson D. (2003) Conserving wild bees for crop pollination. International Journal of Food, Agriulture and the Environment 1: 142-144.

Güler Y. (2011) The wild bee fauna of Afyonkarahisar province: Andrenidae, Anthophoridae and Megachilidae (Hymenoptera: Apoidea). Linzer Biologische Beiträge 43(1): 731-746.

Güler Y. (2012) Sultandağı (Afyonkarahisar) kiraz bahçelerinde Osmia (Hymenoptera: Megachilidae) türlerine yönelik yürütülen yapay yuva çalıșmaları. Bitki Koruma Bülteni 52(4): 325- 336.

Güler Y., Dikmen F. (2013) Potential bee pollinators of sweet cherry in inclement weather conditions. Journal of the Entomology Research Society 15(3): 9-19. 
Güler Y., Sorkun K. (2010) Analysis of pollen collected by Andrena flavipes Panzer (Hymenoptera: Andrenidae) in sweet cherry orchards, Afyonkarahisar province of Turkey. Psyche 2010: 1-5. DOl: 10.1 155/2010/160789

Güler Y., Aytekin A. M., Dikmen F. (2011) Bombini and Halictidae (Hymenoptera: Apoidea) fauna of Afyonkarahisar province of Turkey. Journal of the Entomological Research Society 13(1): 1-22.

Hijmans R. J., Guarino L., Bussink C., Mathur P., Cruz M., Barrantes I., Rojas E. (2005) DIVA-GIS, version 5.2. A geographic information system for the analysis of biodiversity data. Manual. Available at: http://www.diva-gis.org

Holzschuh A., Steffan-Dewenter I., Kleijn D., Tscharntke T. (2007) Diversity of flower-visiting bees in cereal fields: effects of farming system, landscape composition and regional context. Journal of Applied Ecology 44: 41 -49.

Huang Z. (2003) The other bees: alternative pollinators for tree and small fruits. Fruit Crop Advisory Team Alert, Michigan State University 18(6): 9-10.

Irvine K. M., Woods S. A. (2007) Evaluating shading bias in Malaise and window-pane traps. Journal of the Acadian Entomological Society 3: 38-48.

McAleece N., Gage J. D. G., Lambshead P. J. D., Paterson G. L. J. (1997) BioDiversity. Professional statistics analysis software. Scottish Association for Marine Science.

Michener C. D. (2000) The Bees of the World. The Johns Hopkins University Press. Baltimore, USA. 913 pp.

Oertli S., Müller A., Dorn S. (2005) Ecological and seasonal pattern in the diversity of a species-rich bee assemblage (Hymenoptera: Apoidea: Apiformes). European Journal of Entomology 102: 53-63.

Osychnyuk A. Z., Panfilov D. V., Ponomareva A. A. (1978) Nadsem. Apoidea - Pchelinye. In: Medvedev G. S. (Ed.) Opredelitel" nasekomyh Evropejskoj chasti SSSR, 3. Pereponchatokrylye, pt. 1. Akademija Nauk SSSR. Leningrad: 279-519.

Özbek H. (2008) Türkiye'de iliman iklim meyve türlerini ziyaret eden böcek türleri. Uludağ Arıcilık Dergisi 8(3): 92-103.

Özbek H., Zanden G. van der (1996) A preliminary review of the Megachilidae of Turkey part V, supplement to parts I-IV (Hymenoptera: Apoidea). Türkiye Entomoloji Dergisi 20(1): 3-17.
Pesenko Yu. A. (1978) Tablica dla opedelenya semeystv nadsem. Apoidea. In: Medvedev G. S. (Ed.) Opredelitel nasekomihewropeyskoy chasti SSSR. Tom 3. Pereponchatokrilye. Chast 1. Nauka Leningradskoe Otdelenie. Leningrad: 280-281.

Pesenko Yu. A. (1984) A subgeneric classification of bees of the genus Halictus Latreille sensu stricto (Hymenoptera, Halictidae). Entomologicheskoe Obozrenie 63(3): 340-357 [in Russian with English summary. English translation: Entomological Review 1985 63(3): 1-20)].

Pesenko Yu. A. (1985) Systematics of the bees of the genus Halictus Latreille (Hymenoptera, Halictidae) with a description of $7^{\text {th }}$ and $8^{\text {th }}$ metasomal sterna of males: subgenus Monilapis Cockerell. Trudy Zoologicheskogo Instituta, Akademiia Nauk SSSR 132: 77-105.

Pesenko Yu. A. (1986) An annotated key to the Palaearctic species of bees of the genus Lasioglossum sensu stricto (Hymenoptera, Halictidae) for females, with descriptions of new subgenera and species. Trudy Zoologicheskogo Instituta, Akademiia Nauk SSSR 159: 113-151.

Pesenko Yu. A., Banaszak J., Radchenko V.G., Cierzniak T. (2000) Bees of the family Halictidae (excluding Sphecodes) of Poland: taxonomy, ecology, bionomics. Bydgoszcz Press. Bydgoszcz, Poland. 348 pp.

Rossi J., Gamba U., Pinna M., Spagnolo S., Visentin C., Alma A. (2006) Hoverflies in organic apple orchards in NorthWestern Italy. Bulletin of Insectology 59(2): 111 - 114.

Roversi A., Ughini V. (1996) Influence of weather conditions of the flowering period on sweet cherry fruit set. In: Proceedings of the International Cherry Symposium. Budapest - Hungary. 14-18 June 1993. Acta-Horticulturae 410: 427-433.

Scheuchl E. (2000) Illustrierte bestimmungstabellen der wildbienen Deutschlands und Österreichs. Band 1: Anthophoridae. $2^{\text {nd }}$ revised edition. Preisinger KG. Landshut. $158 \mathrm{pp}$.

Scheuchl E. (2006) Illustrierte bestimmungstabellen der wildbienen Deutschlands und Österreichs. Band 2: Megachilidae und Melittidae. Preisinger KG. Landshut. 192 pp.

Sharley D. J., Hoffmann A. A., Thomson L. J. (2008) The effects of soil tillage on beneficial invertebrates within the vineyard. Agricultural and Forest Entomology 10: 233-243. 
Steffan-Dewenter l., Leschke K. (2003) Effects of habitat management on vegetation and above-ground nesting bees and wasps of orchard meadows in Central Europe. Biodiversity and Conservation 12: 1953-1968.

Tadauchi O., Matsumura T. (2007) The genus Andrena collected from Nepal (Hymenoptera, Andrenidae) with redescriptions of some types of Andrena described from North India. Esakia 47: 1-20.

Terzo M., Iserbyt S., Rasmont P. (2007) Revision des Xylocopinae (Hymenoptera: Apidae) de France et de Belgique. Annales De La Societe Entomologique De France 43(4): 445-492.

Townes H. (1972) A light-weight malaise trap. Entomogical News 83: 239- 247.
Tscheulin T., Neokosmidis L., Petanidou T., Settele J. (201 1) Influence of landscape context on the abundance and diversity of bees in Mediterranean olive groves. Bulletin of Entomological Research 101: 557-564.

Tuell J. K., Ascher J. S., Isaacs R. (2009) Wild bees (Hymenoptera: Apoidea: Anthophila) of the Michigan highbush blueberry agroecosystem. Annals of the Entomological Society of America 102: 275-287.

Vicens N., Bosch J. (2000) Pollinating efficacy of Osmia cornuta and Apis mellifera (Hymenoptera: Megachilidae, Apidae) on ,red delicious' apple. Environmental Entomology 29(2): 235-240.

\section{Appendix 1:}

\section{The list of described bees}

\begin{tabular}{|c|c|c|c|c|c|c|c|c|}
\hline \multirow[b]{2}{*}{ No } & \multirow[b]{2}{*}{ Species } & \multicolumn{3}{|c|}{$1^{\text {st }}$ orchard } & \multicolumn{2}{|c|}{$2^{\text {nd }}$ orchard } & \multicolumn{2}{|c|}{$3^{\text {rd }}$ orchard } \\
\hline & & $\begin{array}{c}2007 \\
\text { (10 traps) }\end{array}$ & $\begin{array}{c}2008 \\
\text { (3 traps) }\end{array}$ & $\begin{array}{c}2009 \\
\text { (3 traps) }\end{array}$ & $\begin{array}{c}2008 \\
\text { (1 trap) }\end{array}$ & $\begin{array}{c}2009 \\
\text { (1 trap) }\end{array}$ & $\begin{array}{c}2008 \\
\text { (1 trap) }\end{array}$ & $\begin{array}{c}2009 \\
\text { (1 trap) }\end{array}$ \\
\hline 1 & Andrena bicolor & 110 & 0 & 0 & 0 & 0 & 0 & 0 \\
\hline 2 & Andrena dorsata & 2 & 3 & 75 & 1 & 5 & 0 & 0 \\
\hline 3 & Andrena flavipes & 37 & 30 & 227 & 4 & 1 & 6 & 0 \\
\hline 4 & Andrena limata & 4 & 0 & 11 & 0 & 1 & 0 & 0 \\
\hline 5 & Andrena thoracica & 4 & 1 & 1 & 1 & 1 & 0 & 0 \\
\hline 6 & Bombus argillaceus & 0 & 0 & 1 & 0 & 0 & 0 & 0 \\
\hline 7 & Bombus terrestris & 1 & 0 & 0 & 0 & 0 & 0 & 0 \\
\hline 8 & Cubitalia parvicornis & 1 & 9 & 13 & 1 & 15 & 1 & 2 \\
\hline 9 & Eucera chrysopyga & 0 & 0 & 41 & 0 & 18 & 0 & 0 \\
\hline 10 & Eucera curvitarsis & 5 & 74 & 17 & 0 & 2 & 1 & 0 \\
\hline 11 & Eucera flavicornis & 4 & 3 & 4 & 0 & 0 & 0 & 0 \\
\hline 12 & Eucera interrupta & 2 & 0 & 2 & 0 & 2 & 0 & 2 \\
\hline 13 & Eucera parnassia & 3 & 85 & 19 & 1 & 0 & 0 & 0 \\
\hline 14 & Evylaeus aeratus & 20 & 0 & 3 & 0 & 19 & 2 & 9 \\
\hline 15 & Evylaeus albipes & 0 & 1 & 0 & 0 & 0 & 0 & 0 \\
\hline 16 & Evylaeus anellus & 14 & 1 & 0 & 6 & 8 & 0 & 2 \\
\hline 17 & Evylaeus annulipes & 5 & 0 & 0 & 0 & 1 & 0 & 0 \\
\hline 18 & Evylaeus brevicornis & 0 & 0 & 0 & 0 & 1 & 0 & 0 \\
\hline 19 & Evylaeus calceatus & 0 & 0 & 0 & 4 & 0 & 0 & 0 \\
\hline 20 & Evylaeus clypearis & 3 & 0 & 0 & 0 & 0 & 0 & 0 \\
\hline 21 & Evylaeus crassepunctatus & 0 & 1 & 0 & 8 & 5 & 0 & 0 \\
\hline 22 & Evylaeus euboeensis & 10 & 1 & 0 & 2 & 0 & 0 & 0 \\
\hline 23 & Evylaeus glabriusculus & 33 & 0 & 45 & 0 & 18 & 0 & 0 \\
\hline 24 & Evylaeus interruptus & 2 & 0 & 0 & 0 & 0 & 0 & 0 \\
\hline 25 & Evylaeus laticeps & 2 & 0 & 0 & 0 & 0 & 0 & 0 \\
\hline 26 & Evylaeus limbellus & 2 & 0 & 0 & 0 & 1 & 2 & 0 \\
\hline 27 & Evylaeus linearis & 166 & 112 & 10 & 6 & 12 & 6 & 1 \\
\hline 28 & Evylaeus lucidulus & 4 & 2 & 0 & 2 & 4 & 0 & 0 \\
\hline 29 & Evylaeus malachurus & 230 & 51 & 18 & 32 & 12 & 3 & 0 \\
\hline 30 & Evylaeus marginatus & 341 & 14 & 11 & 1 & 2 & 1 & 0 \\
\hline 31 & Evylaeus marginellus & 2 & 0 & 0 & 0 & 0 & 0 & 0 \\
\hline 32 & Evylaeus mediterraneus & 2 & 8 & 0 & 0 & 0 & 0 & 0 \\
\hline 33 & Evylaeus mesosclerus & 5 & 0 & 0 & 0 & 3 & 0 & 0 \\
\hline 34 & Evylaeus minutissimus & 17 & 0 & 1 & 0 & 3 & 0 & 1 \\
\hline 35 & Evylaeus morio & 59 & 10 & 28 & 8 & 17 & 1 & 7 \\
\hline 36 & Evylaeus obscuratus & 3 & 3 & 1 & 0 & 0 & 0 & 0 \\
\hline
\end{tabular}




\begin{tabular}{|c|c|c|c|c|c|c|c|c|}
\hline 37 & Evylaeus pauxillus & 8 & 4 & 0 & 0 & 0 & 1 & 1 \\
\hline 38 & Evylaeus politus & 1 & 0 & 0 & 0 & 0 & 0 & 0 \\
\hline 39 & Evylaeus punctatissimus & 0 & 1 & 0 & 0 & 2 & 0 & 0 \\
\hline 40 & Evylaeus puncticollis & 8 & 0 & 1 & 0 & 0 & 0 & 0 \\
\hline 41 & Evylaeus pygmaeus & 0 & 0 & 0 & 0 & 0 & 0 & 1 \\
\hline 42 & Evylaeus quadrisignatus & 2 & 0 & 0 & 0 & 0 & 0 & 0 \\
\hline 43 & Evylaeus setulellus & 4 & 0 & 0 & 0 & 1 & 0 & 1 \\
\hline 44 & Evylaeus trichopygus & 0 & 0 & 0 & 0 & 1 & 0 & 0 \\
\hline 45 & Evylaeus tricinctus & 7 & 0 & 0 & 0 & 0 & 0 & 0 \\
\hline 46 & Evylaeus villosulus & 29 & 0 & 3 & 0 & 2 & 0 & 0 \\
\hline 47 & Halictus asperulus & 2 & 1 & 0 & 0 & 3 & 0 & 1 \\
\hline 48 & Halictus cf. graecus & 1 & 0 & 0 & 0 & 0 & 0 & 0 \\
\hline 49 & Halictus cochlearitarsis & 4 & 1 & 1 & 0 & 2 & 0 & 0 \\
\hline 50 & Halictus compresus & 0 & 1 & 0 & 0 & 0 & 0 & 0 \\
\hline 51 & Halictus Iuganicus & 26 & 2 & 17 & 0 & 2 & 0 & 0 \\
\hline 52 & Halictus maculatus & 43 & 3 & 1 & 0 & 4 & 0 & 1 \\
\hline 53 & Halictus patellatus & 10 & 2 & 3 & 0 & 0 & 0 & 0 \\
\hline 54 & Halictus pentheri & 9 & 0 & 3 & 0 & 2 & 0 & 0 \\
\hline 55 & Halictus quadricinctus & 2 & 0 & 0 & 0 & 0 & 0 & 0 \\
\hline 56 & Halictus resurgens & 13 & 2 & 4 & 0 & 0 & 0 & 0 \\
\hline 57 & Halictus sajoi & 7 & 0 & 1 & 0 & 1 & 0 & 0 \\
\hline 58 & Halictus senilis & 3 & 0 & 5 & 0 & 0 & 0 & 0 \\
\hline 59 & Halictus sexcinctus & 3 & 0 & 0 & 0 & 0 & 0 & 0 \\
\hline 60 & Halictus tetrazonianellus & 2 & 0 & 0 & 0 & 0 & 0 & 0 \\
\hline 61 & Lasioglossum acephaloides & 5 & 0 & 0 & 0 & 0 & 0 & 0 \\
\hline 62 & Lasioglossum aegyptiellum & 2 & 0 & 2 & 0 & 2 & 0 & 0 \\
\hline 63 & Lasioglossum discum & 20 & 0 & 2 & 0 & 2 & 0 & 0 \\
\hline 64 & Lasioglossum equestre & 2 & 0 & 0 & 0 & 0 & 0 & 0 \\
\hline 65 & Lasioglossum fallax & 36 & 1 & 0 & 0 & 0 & 0 & 0 \\
\hline 66 & Lasioglossum lativentre & 5 & 0 & 0 & 0 & 0 & 0 & 0 \\
\hline 67 & Lasioglossum leucozonium & 67 & 0 & 6 & 1 & 8 & 0 & 3 \\
\hline 68 & Lasioglossum quadrinotatum & 4 & 1 & 0 & 0 & 0 & 0 & 0 \\
\hline 69 & Lasioglossum subfasciatum & 2 & 0 & 0 & 0 & 0 & 0 & 0 \\
\hline 70 & Osmia brevicornis & 1 & 1 & 4 & 0 & 3 & 0 & 0 \\
\hline 71 & Osmia caerulescens & 30 & 12 & 14 & 2 & 7 & 2 & 0 \\
\hline 72 & Osmia bicornis & 20 & 3 & 31 & 0 & 2 & 3 & 2 \\
\hline 73 & Osmia melanura & 0 & 0 & 0 & 0 & 7 & 0 & 0 \\
\hline 74 & Osmia nigriventris & 1 & 0 & 0 & 0 & 0 & 0 & 0 \\
\hline 75 & Rophites hartmanni & 1 & 0 & 0 & 0 & 0 & 0 & 0 \\
\hline 76 & Seladonia cf. desertorum & 2 & 0 & 0 & 0 & 0 & 0 & 0 \\
\hline 77 & Seladonia pollinosa & 16 & 0 & 7 & 0 & 0 & 0 & 0 \\
\hline 78 & Seladonia seladonia & 11 & 0 & 0 & 0 & 9 & 0 & 0 \\
\hline 79 & Seladonia smaragdula & 22 & 0 & 0 & 0 & 7 & 0 & 0 \\
\hline 80 & Seladonia verticalis & 5 & 1 & 10 & 0 & 2 & 0 & 2 \\
\hline 81 & Seladonia vestita & 151 & 0 & 19 & 0 & 1 & 0 & 0 \\
\hline 82 & Sphecodes albilabris & 0 & 0 & 1 & 0 & 0 & 0 & 0 \\
\hline 83 & Xylocopa valga & 0 & 0 & 2 & 0 & 0 & 0 & 0 \\
\hline
\end{tabular}

\section{Appendix 2:}

The list of described plants from the orchards and their pollinator needs

\begin{tabular}{ccccccc}
\hline No & Species & Family & Pollinator & $\begin{array}{c}1^{\text {st }} \\
\text { orchard }\end{array}$ & $\begin{array}{c}2^{\text {nd }} \\
\text { orchard }\end{array}$ & $\begin{array}{c}3^{\text {rd }} \\
\text { orchard }\end{array}$ \\
\hline 1 & Senecio vernalis Waldst. \& Kit. & Asteraceae & + & + & + & - \\
\hline 2 & Taraxacum Scaturiginosum G. Hagl. & Asteraceae & + & + & - & - \\
\hline 3 & Taraxacum macrolepium Schischkin & Asteraceae & + & - & + & - \\
\hline 4 & Taraxacum turcicum van Soest & Asteraceae & + & + & + & - \\
\hline 5 & Tripleurospermum elongatum (Fisch. \&Mey) Bornm. & Asteraceae & $?$ & + & - & - \\
\hline 6 & Anchusa undulata L. Ssp. hybrida (Ten.) Cout. & Boraginaceae & + & + & + & - \\
\hline
\end{tabular}




\begin{tabular}{|c|c|c|c|c|c|c|}
\hline 7 & Asperugo procumbens L. & Boraginaceae & $?$ & - & + & - \\
\hline 8 & Myosotis stricta Link ex Roem. \&Schult. & Boraginaceae & + & - & + & - \\
\hline 9 & Capsella bursa-pastoris (L.) Medik. & Brassicaceae & + & + & + & + \\
\hline 10 & Вarbarea vulgaris R.Br. & Вrassicaceae & + & + & + & - \\
\hline 11 & Chorispora syriaca Boiss. & Brassicaceae & + & - & + & - \\
\hline 12 & Descurainia sophia (L.) Webb ex Prantl & Brassicaceae & - & - & + & - \\
\hline 13 & Erophila verna (L.) Chevall. subsp. verna & Brassicaceae & + & + & + & - \\
\hline 14 & Hymenolobus procumbens (L.) Nutt. ex Torrey \&Gray & Brassicaceae & $?$ & + & - & - \\
\hline 15 & Malcolmia africana (L.) R.Br. & Brassicaceae & $?$ & - & + & - \\
\hline 16 & Thlaspi perfoliatum L. & Вrassicaceae & + & + & + & - \\
\hline 17 & Cerastium gracile Dufour & Caryophyllaceae & + & + & - & - \\
\hline 18 & Cerastium anomalum Waldst. \& Kit & Caryophyllaceae & + & + & + & + \\
\hline 19 & Medicago orbicularis (L.) Bart. & Fabaceae & + & + & - & - \\
\hline 20 & Trifolium repens L. & Fabaceae & + & + & - & - \\
\hline 21 & Erodium cicutarium (L.) L'Herit ssp. cicutaria & Geraniaceae & + & + & - & - \\
\hline 22 & Lamium amplexicaule L. & Lamiaceae & + & + & + & - \\
\hline 23 & Lamium garganicum L. & Lamiaceae & + & + & - & - \\
\hline 24 & Lamium purpureum L. var. рuгрuгеum & Lamiaceae & + & - & + & - \\
\hline 25 & Gagea peduncularis (J. \& C. Persl) Pascher & Liliaceae & + & + & + & - \\
\hline 26 & Muscari neglectum Guss & Liliaceae & + & + & + & - \\
\hline 27 & Ornithogalum umbellatum L. & Liliaceae & + & + & + & - \\
\hline 28 & Fumaria asepala Boiss. & Papaveraceae & + & - & + & - \\
\hline 29 & Fumaria officinalis L. & Papaveraceae & + & + & - & - \\
\hline 30 & Hypecoum procumbens L. & Рapaveraceae & $?$ & - & + & - \\
\hline 31 & Androsace maxima L. & Primulaceae & $?$ & + & - & - \\
\hline 32 & Adonis aestivalis L. subsp. aestivalis & Ranunculaceae & + & + & + & + \\
\hline 33 & Caltha polypetala Hochst. ex Lorent & Ranunculaceae & + & + & - & - \\
\hline 34 & Ceratocephalus falcatus (L.) Pers & Ranunculaceae & $?$ & - & + & - \\
\hline 35 & Veronica campylopoda Boiss. & Scrophulariaceae & + & - & + & - \\
\hline 36 & Veronica hederifolia L. & Scrophulariaceae & + & + & - & + \\
\hline 37 & Veronica triloba (Opiz) Kerner & Scrophulariaceae & + & + & + & - \\
\hline 38 & Veronica michauxii Lam. & Scrophulariaceae & + & - & - & + \\
\hline
\end{tabular}

+ = pollinator is needed; - = pollinator is not needed; ? = unknown 